\title{
America's pyramids: Presidents and their libraries
}

\author{
Richard J. Cox* \\ Department of Library and Information Sciences, University of Pittsburgh, School of Information Sciences, \\ Pittsburgh, PA 15260, USA
}

\section{Introduction}

As the days pass, preparations continue to establish the William Jefferson Clinton Presidential Library in Little Rock, Arkansas. America's tenth Presidential Library is in its early period of formation. In Fall 2000 a former auto dealership's building, with 30,000 thousand square feet of space and plans for adding another 20,000 square feet, in Little Rock, Arkansas began as the home for the team of archivists organizing Clinton's presidential records. Projected to be the largest of the Presidential Libraries, the records and memorabilia will fill 67,000 cubic feet while the William J. Clinton Presidential Foundation raises funds to build a permanent home for the library. Quietly, with little fanfare, begins yet one more Presidential Library in a system that has been lauded, lambasted, and lamented since its start more than sixty years ago with the founding of the Franklin Delano Roosevelt Library in New York.

While the stones of this new pyramid are dragged into place, the federal government continues in its struggles to resolve the ownership of the records of one of its deceased pharaohs. On June 12, 2000 the U.S. Justice Department approved the payment of $\$ 18$ million to the estate of former President Richard M. Nixon in "compensation" for records seized when he resigned in 1974. The bulk of the funds, nearly half, would be going to the Nixon Presidential Library in Yorba Linda, California. Peter Kornbluh, senior analyst at the National Security Archives, remarked, "It is unfortunate that taxpayers have to pay for what is already rightfully theirs."' It is also unfortunate that yet another presidential library has gained funding that will keep it in the business of commemorating the legacy of this particular president, both competent and disgraced, in a manner that sees no end and that is contributing to a system spinning out of control. The original pyramids were carried on the

*Tel.: + 1-412-624-3245; fax: + 1-412-648-7001.

E-mail address: rcox@mail.sis.pitt.edu (R.J. Cox).

0740-624X/02/\$ - see front matter $\odot 2002$ Elsevier Science Inc. All rights reserved.

P1 1: S0740-624X(01)00094-6 
backs of slaves and servants in the ancient world. Their American counterparts have seemingly become a part of the permanent public memory business, a process with no end in sight as long as the American Republic exists or until the American people and taxpayers say, enough. When travel writer William Zinsser declared that Mount Rushmore was unsurpassed in being an iconic place-"nowhere had the nation's icons been so baldly foisted on the nation-four pharaohs in the sky"2-he was wrong. The growing number of Presidential Libraries rival Mount Rushmore as the modern equivalent of the pyramids.

A few years ago, in 1997, it was estimated the other nine libraries were managing nearly 269 million pages of textual materials, five million photographs, fourteen million feet of motion-picture film, seventy-eight thousand hours of disc, audiotape, and videotape recordings, and 280,000 museum objects.3 Today, the National Archives Web site indicates that the ten libraries and the Nixon Presidential Materials staff maintain "over 300 million pages of textual materials; 7 million photographs; 14.5 million feet of motion picture film; 83,000 hr of disc, audiotape, and videotape recordings; and 350,000 museum objects."4 For the advocates of the library system, and there are many such advocates, the richness of these records is testimony itself to the inspired vision leading to their creation. But there are many questions tugging at the stones supporting the system. At what cost has the system been built? Have these libraries made us, the American people, understand better the nature of the Presidency? Are the President and his office being held accountable to the people and the government? Are the records in the libraries as freely accessible as they should be? And, just what seems to be the purpose-research, celebration, memory-of the libraries? Although hundreds of articles have been published, numerous books rolled off of presses, thousands of press releases issued, and millions of people visited these institutions, many of these-and other-questions linger.

\subsection{What is the purpose of presidential libraries?}

The purpose of Presidential Libraries seems, on the surface, so very simple. One of the pre-eminent archivists of his time, Philip Brooks (then director of the Truman library), wrote in 1962 that the "basic objective of these Presidential Libraries is to preserve and to make available in one place all the historical materials from one Presidential Administration."s What more could we ask, and, indeed, this rationale has been given over and over again during the past half century, by both those within the system and those researchers coming to use the records. Yet, while the libraries were built originally for housing the records, it is the museums today that seem to get the most attention, with more than one and a half million visitors annually walking through the exhibitions.6 A decade ago, then Archivist of the United States Don W. Wilson remarked, "To my mind, presidential libraries have made and are making two significant contributions. One is the timely availability of a President's papers. Most often, archival research is under way within five years of a President leaving office, a circumstance unequalled anywhere else in the world. The second contribution deals with public awareness. Presidential museums have succeeded admirably, I believe, in raising public consciousness of the burdens of presidential decisions ...."7 However, both of these assertions have not necessarily been proved. Like many other creations of the Federal 
government, the libraries seem to have taken on a life of their own, becoming immune to suggestions that the system may have outlived its usefulness.

\subsection{Presidential papers before presidential libraries}

Such a perspective has been fueled by many factors, but none more important than the checkered history of Presidential records before the establishment of the first library. As another prominent archivist, Lester Cappon, remarks, before 1939 and the creation of the Franklin Delano Roosevelt Library, the history of the Presidential records was that of a "variegated record of conscientious preservation, of accidental or willful destruction, of crass commercialism, and of sheer indifference." \$ Indeed, the history of the earliest Presidential records is a difficult one. Before the National Archives, the Presidents, as they left office, simply carted their papers off with them, considering them their personal property. Here, we see these documents left vulnerable to the vagaries of history. Some of these records perished in fires, as did those of Martin Van Buren, William Henry Harrison, John Tyler, and Zachary Taylor. The papers of Warren Harding had an even more checkered existence. After his death, his widow burned about half of his personal papers and many of his public records were shuffled off into the basement of the White House. When Mrs. Harding died, she left the remains of her spouse's records to the Harding Memorial Association, a private group guarding access to these papers as if they were crown jewels. Finally, in 1963, the Harding papers were placed in the Ohio Historical Society. Such stories of neglect or outright destruction are hauled out by supporters of the library system, in an effort to argue that the only other solution is the present system of libraries, ignoring, of course, that there may be simple alternatives.

A working solution to the problem of the Presidential papers seemed to present itself after the establishment of the Library of Congress in 1800. As Congress heard of the fate of the papers of former Presidents, and as it moved into the mode of supporting documentary publishing and the copying of records related to the American Revolution in foreign archives, it appropriated funds for purchasing these papers and placing them in the Library of Congress. In the 1830s and 1840s, the Library of Congress acquired the papers of George Washington, Thomas Jefferson, James Madison, and James Monroe. By the late 1930s, the Library of Congress held the papers of 22 Presidents. All seemed well, except that the Library had to acquire these papers through elaborate negotiations, faced the not always easy task of obtaining Congressional action to purchase them, and was dependent on the former Presidents or heirs as to what records were received. That such important records were left to such a flexible and uncertain arrangement might reflect the more informal nature of the Presidency before the twentieth century, but this arrangement did not bode well for the growing importance of this office or the accountability of the Presidency to Congress and, most significantly, the American people.

The matter of private ownership seems to stem from two aspects inherent in the establishment of the office of the President in the formation of our national government, the precedent set by the first President and the lack of provision for these records in the days before the establishment of a national archives. Washington set the precedent of private ownership when he packed up and took his papers with him at the end of his administration, 
but even he seemed uneasy about this as a workable solution. Washington, in an April 3, 1797 letter to James McHenry indicated that he had thought of erecting a building "for the accommodation and security of my military, civil, and private papers which are voluminouse, and may be interestg, $" !^{\circ}$ reflecting here about a separate building on his estate. Of course, everything Washington did was a precedent, and in the case of his personal papers he simply seemed to have no alternative. It was a new government, and its recordkeeping, while provided for in its earliest foundations, was often haphazard or, at best, uncertain at a time of constructing a fragile framework for governance.

Even by the twentieth century, this attitude seemed not to have changed very much. In 1916 former President William Howard Taft noted that the concept of individual ownership of presidential files might lead to a "loss in public record [of] some of the most interesting documents of governmental origin bearing on the history of an administration," but that he had no legal alternative for this.' The supposed success of the Presidential library system has also caused some, especially those from within the system, to reinterpret earlier approaches to managing such records. Archivist Ray Geselbracht notes that the "Library of Congress simply did not offer sufficient inducement to a president and his family to give up the still very potent private property claim to his papers," as well as offering only shelf space rather than a memorial.' These, and other, weaknesses have caused many individuals to worry that the Presidential Library system, no matter what's its weaknesses may be, would be lost, endangering the records once again to chance and haphazard care. ${ }^{3}$ Archivist Geselbracht again argues, "This era of personal custody was clearly an uncertain one, which could have been acceptable only to a people who were content to leave the preservation of their national memory to chance. By the beginning of the twentieth century, such carelessness was no longer considered tolerable, and a counter claim of public interest was raised." 14 Archivist of the United States James B. Rhoads offered some reasons for why this precedent was created including the lack of "institutional complexity which exists in the White House today," or an "adequate public facility" and the fact that Presidents "wished to maintain some degree of control over the files they created while in office." It is, of course, the public interest that must now be re-evaluated in light of a half-century of Presidential Libraries. Has the "era of personal custody" really substantially changed in the nature of Presidential Libraries that have evolved since the late 1930s?

Appealing to the Presidents' dilemma prior to the Roosevelt Library provides, of course, only a limited view of the issues faced about these records, their preservation, and their use. In the early days of the formation of the Roosevelt Library, Archivist of the United States R. D. W. Connor remarked, "I recently heard the daughter of a former president feelingly describe the heavy physical and financial burden that her father's papers imposed upon his family while they were trying to reduce them to some semblance of order preparatory to depositing them in the Library of Congress." Such sentiments seem to suggest that the notion of these special libraries was both a necessary and a brilliant idea. However, many Presidents have also asserted their right to private control of their records as part of executive privilege. While we have become accustomed to tussles between the President and Congress or the media, there has been tension about this for a very long time. In 1886 Grover Cleveland was demanded by the Senate for certain records related to the removal of a U.S. district attorney, but Cleveland refused on the basis that such records were "purely unofficial 
and private, not infrequently confidential, and having reference to the performance of a duty exclusively mine."" These tensions remain very much a factor in the later, and supposedly more enlightened, legislative acts governing Presidential records.

\subsection{FDR and the origins of the president library}

It is within this concept of the privilege Presidents have believed to possess over their papers that the beginnings of the Presidential Library system must be viewed, a perspective that will become obvious as to its importance later in this essay. Franklin Delano Roosevelt was obviously thinking about an idea for a library very early in his administration. In 1937 Roosevelt's legal counsel and speechwriter, Samuel I. Rosenman, was working on the publication of the President's Public Papers to generate finances to support a library, drawing some criticism from the press and others because they saw this as a personal profit issue, before they knew about the plans for the library.' The criticisms subsided when FDR announced his plans for a library at a press conference on December 10, 1938, plans ultimately endorsed by Congress with legislation passed on July 18, 1939 placing the library under the Archivist of the United States with a separate Board of Trustees. ${ }^{19}$ Roosevelt's motivations seemed to stem from concerns about the pace by which the National Archives

staff were preparing records for use, the growing volume of records and the new technologies (especially sound recordings) creating these documents, and the unique importance of his particular era. ${ }^{20}$ Yet, there also was an amazing personal sense of the importance of archives that has seemed to transform Roosevelt into a kind of hero by those who advocate the value of the Presidential Library system. That it has been largely archivists and staff associated with these Libraries who have expressed such views perhaps reflects a sincere dedication to the management and use of these records. At the same time, such views might be the result of a myopic vision regarding the weaknesses of the library system.

An eyewitness to and participant in the creation of the first Presidential Library, Waldo Gifford Leland reminisced that Roosevelt thought "that the happiest day of his life would be that on which he saw the Army trucks, loaded with his papers, leave the White House grounds bound for Hyde Park." Leland continued, "He had the instincts and the active interests of the historian, as the earlier President Roosevelt had had, and he longed to indulge them; and he had the instincts of the collector, as well . ${ }^{\text {i2' }}$ The Archivist of the United States remarked in 1939 that "Franklin D. Roosevelt is the nation's answer to the historian's prayer. Never before has the White House sheltered a president who has had so clear an understanding and so sympathetic an appreciation of the historian's unceasing petition for the raw materials of his science." ${ }^{22}$ The result of such views was that Roosevelt, primarily by those writing from within the National Archives and the library system itself, was christened a champion of heroic stature.

Roosevelt was seen as a "born preserver," with a "direct relationship between the President's wish to preserve his several collections and the decision to construct an archival depository on his mother's estate at Hyde Park." ${ }^{23}$ When Roosevelt died, the Society of American Archivists ran an obituary calling him the Society's "most illustrious member." "Certainly no one had a greater appreciation of the importance of archives or better understanding of the complexity and magnitude of the problem they present," recounted the 
Society's leaders. "Someday it may be said that in the field of archival science he was a man ahead of his generation, for he not only recognized the problems but made sound suggestions for their solution." ${ }^{24}$ A staff member at the FDR library, two decades after Roosevelt's death, similarly mused, "We at Hyde Park are particularly fortunate in dealing with a President who liked papers and records, who wanted to see them for himself, and who liked to keep the record at hand. Papers did not flow in to his desk from a Department and out again with approvals or disapprovals. They stayed as part of the Presidential files .... We are fortunate also that he loved detail. He was not satisfied with 'the chain of command' and official reports forwarded up through proper channels; he encouraged in addition direct reports to him from his ambassadors, friends, and acquaintances, and the general public-exasperating perhaps for administrators but a boon to researchers. Just as he considered it desirable to keep all drafts of his speeches, so also he liked to retain the full story of plans and decisions and of actions and events." ${ }^{25}$ One might believe, reading these platitudes, that the Roosevelt and other subsequent libraries have had nothing but success with the issues regarding the preservation and management of Presidential papers. The truth is, however, that Presidential papers and access to them has remained a source of contention throughout the existence of the Presidential Libraries. Even as I was putting the final touches on this essay, there were delays in opening records from the Reagan administration seemingly because some of the Reagan appointees were now working in the present Bush White House. ${ }^{26}$

While there was intense debate in Congress about this first Presidential library, with one Congressman contending that "only an egocentric megalomaniac would have the nerve to ask for such a measure" 27 and another worrying that the problem won't be the "initial cost, but the upkeep which will eventually become burdensome, ${ }^{28}$ the FDR library set a powerful precedent for other Presidents. The Archivist of the United States accepted the library building in 1940, the museum was opened to the public a year later, and the library was opened for research in 1946. Although many look back on the establishment of this first Presidential Library as a watershed event and one with substantial promise, its origins were not as calm as it appears. While Archivist Connor publicly wrote and spoke about the wonders of this new institution, such as acknowledging that Roosevelt's planning committee "welcomed the president's plan as an opportunity to set up for the first time in this country, under federal control and for the use of the public, an extensive collection of source material relating to a specific period in American history, ${ }^{29}$ he privately worried about the President's role. Connor wrote in his journal, April 3, 1940, "I don't envy the man who takes over the job of administering the FDR Library unless he is able to conform to the ideas-I may say the queer ideas of FDR-about how it ought to be administered!" ${ }^{30}$ Needless to say, many subsequent Presidents have had queer ideas about their papers, as well as their libraries.

\subsection{The presidential library system's evolution and the issues of presidential papers}

Despite whatever problems may have developed or the challenges posed by this library being a completely new type of institution, it seems obvious that other Presidents would want to follow with this precedent. Harry S Truman was uncertain about how to proceed with his administration's records, and he passed leadership on this matter to the National Archives. 
The Archives pressed for passage of the first Presidential Libraries Act, enacted in 1955, seeking to avoid having each President's library be separately debated in Congress and establishing the model (following FDR's actions) that each new library would be privately constructed, then deeded to the federal government. Under this legislation, also following FDR and all of the previous Presidents, the President had complete control of defining his Presidential papers. Shortly thereafter, in 1957, the second Presidential library for Truman's administration was established. 'This was followed by the Eisenhower in 1962 and the Hoover two years later. The growing presence of these libraries, along with the projected continuation of these libraries, resulted in the establishment of an Office of Presidential Libraries within the National Archives in 1964. These libraries were followed by the Kennedy, Johnson, Ford, Carter, Reagan, and Bush. The Clinton Library is now underway in preparations. While there is a Nixon Library, it is not operated as part of the Presidential Library system.

The development of these libraries has not been without controversies. The Kennedy Library was delayed by false starts and controversies in locating it at Harvard (opposed by the Cambridge neighborhood residents). During the Johnson administration, the White House Liaison Office in the National Archives emerged to help prepare the records for transfer, but the rationale for this office was not altogether positive. As two NARA archivists suggest, "The dangers inherent in a liaison office grow from the unequal and incomparable stature and powers of the partners in the liaison. The National Archives and Records Service is a small agency with limited powers of enforcement and persuasion; the White House is a giant with enormous power." ${ }^{33}$ In this statement, we find both explanation and excuse underlying many of the subsequent problems to come, especially in the role of the National Archives but also more broadly in the anemic nature of the archival and historical professions in policing how such records are administered and for what purposes they are preserved.

The greatest controversy has been, of course, that concerning ownership of the Nixon papers. On September 7, 1974 Nixon signed an agreement with the General Service Administration that transferred presidential materials as deposit not gift, restricting access, and giving Nixon the right to withdraw after three years all materials except the tape recordings. Nixon could also destroy tapes after September 1, 1979 and definitely have them destroyed after September 1, 1984 or the President's death. A great public outcry ensued, with twenty different bills introduced into Congress to resolve the situation. The result was the Presidential Recordings and Materials Preservation Act of 1974, an act affirming government ownership over Presidential records for the first time and establishing a study commission to look into the matter of these records. Although Nixon filed suit, the Supreme Court ruled on June 28, 1977 that the new Act was constitutional, and as one archivist noted, the "president's private property claim to his papers has been for all practical purposes denied." ${ }^{34}$ Such assessments proved premature. In the early stages of the Nixon controversy, Archivist of the United States Rhoads stated, "Of all the programs which come under my supervision, this one is prob̧ably the most publicly visible, the most controversial, and the most politically sensitive."

Even more importantly, the initial agreement between Nixon and the GSA broke - the tradition set by FDR and even exaggerated the private property claim made by ex-Presidents before FDR. ${ }^{36}$ The result is a repository that is not formally a part of the Presidential Library 
system because it does not house presidential records or take any tax money for its operation, but runs itself as a museum (except for a relatively small quantity of pre-Presidential papers).' The constant controversy surrounding Nixon, the twenty years of litigation, and the negotiations for the government's purchase of the papers all generated both mixed reactions to the library and arguments once again for a single centralized library for Presidential papers.

These continuing debates occurred as there were studies about what to do with records such as those of the Presidents. The National Study Commission on Records and Documents of Federal Officials issued a report in March 1977, although it did not have much influence on the new legislative act. The Watergate debacle gave the public and lawmakers the need to re-evaluate the question of the nature and ownership of Presidential papers. As one historian and archivist, Lester Cappon, reflected at the time, "Before the Watergate crisis developed, however, few archivists and librarians took a stand in support of the argument that presidential papers are public records." This all changed, however, with Watergate. "What was seldom discussed by archivists a few years ago has been converted into a vital issue through political crisis. The menace of government by men, contemptuous of law, has brought about a reassessment of the records fundamental to government by law, and many archivists are broadening their concept of public records as they consider the nature of the presidential papers." ${ }^{3 \mathrm{~s}}$ This commentary by an archivist provides a somewhat different view about whether this commission and subsequent act was a significant sea change in attitudes about Presidential records. Anna Kasten Nelson, an historian and Commission staff member, concludes, "The Watergate era, the Nixon tapes, the Kissinger telephone transcripts, and the sudden interest in records and documents which followed provided a unique opportunity for archivists and historians to influence publiç policy. Unaccustomed to assuming a role of advocacy, they failed to 'seize the day.' Nelson also believed that one of the study commission's failings was that the staff lacked knowledge about "archival matters." This "meant that too much reliance was placed upon archivists and records managers in the National Archives," meaning, among other things, "there was no thought of examining critically the role played by the National Archives in certain important areas." ${ }^{40}$ Clearly, such views about the weaknesses of the National Archives poses some problems with one obvious alternative to a Presidential Library system, placing all of the Presidential papers within the National Archives.

The Nixon debacle, as well as continuing problems with ownership issues concerning Presidential papers, seemed to present an immense opportunity for the federal government to resolve the outstanding problem facing these records-Presidential records would be declared to be public property and the George Washington legacy finally overturned completely. The Presidential Record Act of 1978 defined carefully "presidential records"separating presidential records into categories of documentary material, presidential records, and personal records-and specified everything created after January 20, 1981 subject to it. Most importantly, the legislation made Presidential papers public records and placed them under the control of the Archivist of the United States. Presidents retained the power to set access restrictions for up to 12 years on records concerning national security, appointments, trade secrets, and financial, medical, and personal records. Diaries and journals can also be declared to be personal. With this legislation, a new watershed in the management of 
Presidential records had been seemingly reached- or, had it? Nelson described the slow start to the Commission's deliberations and its internal politics. While Anna Kasten Nelson can argue there was agreement about the ownership of public papers, she also reported that there were serious differences about the question of access. This resulted in a "loophole" whereby critically important records could be controlled for twelve years after leaving office. ${ }^{41}$

This act was not the final expression of concern about how Presidential records needed to be managed. Many in Congress, as well as citizens, continued to express concern about the financial burdens imposed by the Presidential Libraries. The costs for the annual maintenance of these libraries had increased forty-fold in four decades (from $\$ 63,745$ in 1955 to about $\$ 25$ million dollars in 1994), partly the result of the increased number of these institutions but also the result of the growing complexities of the buildings and programs (the Ford Library was split into two structures-one in Ann Arbor housing the papers and the other in Grand Rapids supporting a museum). The Presidential Libraries Act of 1986 was the result of a protracted debate to limit government support for the presidential libraries. This new act set reporting requirements, architectural and design conditions, and fiscal limitations including the requirement for an operating endowment for the establishment of each new library. The library facilities themselves were limited to 70,000 square feet, as well as requiring an endowment of $20 \%$ of the total cost of the library that would be used for its operation. While this legislation dealt with trying to control the scale of these institutions, it avoided more fundamental questions about the control of Presidential records, including, most importantly, their purpose and value not just for scholars but also for the American people.

The success of this latest effort to legislate the operation of the Presidential Libraries seems marginal given the ongoing controversies about costs, access to the records held there, and other matters. In the mid-1990s, then Speaker of the House of Representatives Newt Gringrich suggested that, in order to lower taxes, that federal aid to Presidential Libraries should be cut and taxpayers can contribute money voluntarily, with the National Archives countering that the current arrangement is a good example of a public-private partnership.

Certainly, these libraries are a good example of how public and private interests can work together, but work together for what? In this case, erecting temples to our former leaders seems not to be the best place to search for such cooperation. Yet, one wonders whether members of Congress, most of whom probably hope to someday be President themselves, will ever be able to bring themselves to give up on the idea of a library and museum dedicated to the memory of a President (that might be them). Often, the negative comments emerging about Presidential Libraries are part of partisan political debates either aimed at eliminating the federal government's support of any institution with cultural and educational values or aimed at a departing President looking forward to enjoying his private library.

The opening of the Reagan Library reflects the continuing mixed results of these institutions. Dedicated in late 1991, the Reagan was the first of these institutions operating under the new act and so subject to the Freedom of Information Act. At its opening, six million pages of records were available, the largest quantity at any Presidential Library opening. Still, the desired location, Stanford University, became too controversial and the library was moved to Ventura County in Southern California. Even within the new guidelines, the facility cost $\$ 57$ million for the 153,000 square feet building-the largest of all Presidential 
Libraries, with the most space $(57,000)$ set aside for document and object storage, with the next largest portion $(29,000)$ for the Reagan Foundation, a hefty space $(22,000)$ for exhibits, and some room (3700) for textual and audiovisual research. Into this facility came 47 million pages of documents in 600 collections, 75,000 gift objects, 15,000 books, and 35,000 serials. ${ }^{43}$ The question one must ask, of course, is whether such a facility enables us to better manage this President's papers or whether this is a fitting and useful memorial for such an individual. Clearly an institution dedicated to a President's memory who seemed to have convenient memory lapses during his administration and who is now battling Alzheimer's is more than a little ironic. Recently the National Capital Memorial Commission objected to a Congressional bill to create a monument to former President Reagan on the National Mall, partly because it violated the 1986 Commemorative Works Act (banning commemorating an individual until at least twenty years after his or her death). ${ }^{44}$ Building these Presidential Libraries right after the Presidents leave office create immediate interest, but once the records are fully open and the researchers slow to a trickle, what do we have left?

The problems with the Presidential Library approach becomes even more complex as we reach the Clinton version. Does this library structure enable anyone to handle electronic mail of the Clinton-Gore administration, the first Administration to recognize or to desire to be part of the Information Age? In an article in the Federal Computer Week, it was chronicled that "Over the past seven years, the White House has produced 30 million to 40 million e-mail messages, according to the National Archives and Records Administration. That's approximately 13,698 a day. And with the administration in its final months, the question is looming: What to do with them?" And the position of the National Archives, also responsible for the Presidential Library system? "The number is more than the Archives can properly preserve with current technology," according to Michael Miller, director of Modern Records Programs at the Archives. "The Archives has asked Congress to include nearly \$1 million in next year's budget for developing better systems for storing electronic records. The agency hopes to test a system designed to rapidly save large numbers of electronic records, especially e-mail messages "One might ask why the Presidential Libraries are not part of the working efforts to resolve this very basic records challenge? The answer to this question is that these libraries serve other purposes and masters.

This brings us back to wondering if Presidential Libraries are imperfect, but nevertheless the best solution for preserving such important documents? Even archivists, tending to be generous in their assessments about these institutions, come up with mixed grades for the libraries. Not too many years ago, a leading archivist, Francis Blouin, concluded, "So the system has evolved balancing the public interest with the particular interests of former presidents. A perfect solution? Well not exactly. The presidential libraries have evolved from that Rooseveltian concept into another kind of institution which has merits but also problems." Francis Blouin thought, "They do provide an institutional framework for the preservation of the history of the administration of the United States. Yet their history has shown that they are fragile, subject to all sorts of forces for which the less visible activities of government have little need for concern." ${ }^{46}$ At the least, these are highly visible institutions needing tremendous re-evaluation.

Needless to say, in the early years of the Presidential Libraries we can find more evidence of gratitude by former Presidents for having separate repositories for their papers. Herman 
Kahn, then Director of the FDR library, in 1953 presented a paper describing the National Archives having a "fiduciary" relationship with papers. "This means that there are great legal, procedural, and technical differences between the status and use made of these papers and those of official archives. This point is emphasized here because an understanding of the fact that none of the manuscript materials in the Roosevelt Library are, legally speaking, official records makes an important difference to scholars who wish to make use of them."47 A couple of generations later such perspectives would be seen as highly questionable. While it is usually not a good idea to use the standards of one era to evaluate another, it is nevertheless difficult to understand why federal archivists and other records professionals would be so easily swayed that this very tenuous relationship is a good idea. Gratitude has certainly turned into a sense of apologetics for the Presidential Library system by those administering the libraries. In 1969 Philip C. Brooks argued that the libraries represent a good solution for the public and private nature of the papers. Brooks described how the "lines are hard to draw among the papers of a President and his associates .... A feasible means of filing separately the papers that are strictly personal, political, or official has not been devised. Often one document will have two or three of these characteristics. More important than trying to make this distinction is that the papers are preserved, in facilities provided by private funds, administered by the Government, and made available to scholars for study. And it is the belief of those who administer them that the Presidential Libraries constitute just such combination of public and private enterprise together, in one institution, to complete the documentation of the Presidency."48 And many would concur with such a statement.

\subsection{The insider's view of presidential libraries}

Advocates from within the Presidential Library system have written scores of articles chronicling their value, and, in fact, one could easily adopt the cynical view that because of the quantity and regularity of writing about this topic by individuals from within the libraries that they set the parameters of public policy discussions about Presidential papers and the Presidential Libraries. Because there are so many sensitive records, the libraries are a "compromise between the competing private and public property claims to presidential

papers,"49 according to archivist Geselbracht. Another insider, William Aeschbacher, lauds the concentration of these libraries within the Midwest.50 The former Director of the Roosevelt Library, Herman Kahn, declares that the growth in government, more people writing letters to the President, and gifts created a situation where the only solution was a separate institution-an excellent one in which everyone benefits. "It should be emphasized that in no case thus far has a President asked Congress to appropriate money for the purchase of land on which a Presidential Library is to be built or for the construction of a building in which his papers, books and mementos are to be housed. The Federal Government receives as a gift not only the priceless collections of papers, books and mementos belonging to the Presidents, but the land, building and equipment necessary properly to house, protect and service them. Thus the government not only comes into possession of a vast collection of historical material at no cost to itself but is provided with the facilities to house them.".51 Another FDR Library staff member, Elizabeth Drewry, believes the libraries have been a boon to collecting personal papers, arguing "Presidential Libraries have awakened many 
institutions to the importance of acquiring modern papers .... As a result of the acquisitions of the Libraries and other institutions, a much larger proportion of source materials will be available for the history of this midcentury than is now in existence for the mid-nineteenth century." ${ }^{\text {s2 }}$ Some have gone even further, such as archivist Geselbracht declaring that the library's "almost incredibly successful resolution of all the problems concerning the preservation and care of presidential papers-as well as its emergence among tourists as an important attraction-made it appear a permanent institution." ${ }^{\mathrm{s} 3}$ Another of the library directors also saw success in the dispersal of the libraries because they are accessible to researchers outside of Washington, D.C. and, with their concentration, "scholars and public can feel the sense and the character of the man and of the period that he represents. A good many researchers have said they think that just the feeling is important, in addition to the research material." ${ }^{54}$ We are buried under the avalanche of good intentions, good will, and great expectations for these institutions.

Despite all these testimonies to the success of the Presidential Libraries, and what they have done for Presidential records, there are still many obvious questions. The recent allegations of deliberate destruction by Vice President Gore's staff of electronic mail, with one top Gore aide retorting to White House computer experts for them to "get lost" and that the vice president's office "would take care of its own records," ought to send an uneasy chill through every American's spine that something is fundamentally wrong with this approach to managing Presidential records ${ }^{55}$ The Clinton Administration's many records-oriented controversies and legal actions, such as the aptly named "Filegate," seem to suggest an environment in which Presidential records play a central role in Presidential prerogatives, privilege, and problems. ${ }^{56}$

Such activities of incumbent Presidents or Vice-Presidents seem to run counter to the attitudes reflected by staff and advocates of their libraries. The first director of the Truman Library, Philip Brooks, expresses the view that these Presidents are doing us, researchers and the public, a huge favor: "After all, the papers have always been considered his when he leaves the White House, he is the person most concerned in their use, and he is the one in whom the writers of various documents have confided. It is quite natural that the concerns of the former President have been a major element in our planning. The remarkable thing is the extent to which he has encouraged the staff to handle the Library and its holdings on a purely professional basis." ${ }^{57}$ While perhaps this was a logical and defensible perspective forty years ago, it certainly is not appropriate today when there is greater recognition that records are important for holding officials accountable to the people and the law of the land, as well as providing substantial historical documentation allowing us to understand the Presidency, the nation, and ourselves. If we are honest, we need to understand that the President, incumbents and former holders of this office often do not want the American people to know certain things, especially as found in their records. The Presidential Library system does not seem to be the ideal solution to such a reality, equivalent to having the fox guard the hen house.

One might also notice that these libraries have been explained in other ways than as repositories for scholarship. Forty years ago the Director of the Truman Library, Philip Brooks, described his institution as a community asset, where the "people and the press of Independence and of Kansas City have claimed the Library as their own. They have 
welcomed it as one of the many cultural elements in the community and have emphasized it as a tourist attraction " Twenty years after that the Director of the Kennedy Library, Dan Fenn, Jr., described his institution as an "educational center." "The resources can be and are being used to give to visitors a better sense of how our system of politics and government functions," he argued. "The library's rich store of case materials can help people understand the process of compromise among competing interests, the process of judicious sacrifice for common goals that enables the public business to be accomplished with a certain degree of responsiveness to public needs and a certain degree of predictable continuity." 59 Just a decade ago, Frank Mackaman, then director of the Ford, lauded their role as museums, noting the "power of the objects they hold and the story of human drama they tell. These same two features also set the museums apart from any other, making them an uncommon cultural and educational storehouse. Where else can Americans so intimately approach our country's most powerful office?" The exhibits in the Presidential Libraries "help make an office that too often seems remote, abstract, and powerful more near to us, more human, and perhaps, more frail "It is difficult to ascertain the effectiveness of these libraries as tourist attraction, cultural center, and educational institution, but it is not difficult to understand that these rationales are a bit of an afterthought to their original purposes of creation-as repositories for the protection of the papers and their use by researchers and the public. Besides, will we have an exhibit on Filegate at the future Clinton Library? Will we learn about the power of these records for understanding American history, the importance of the Presidency, and holding all federal officials-elected and appointed-accountable to the people? It is doubtful that this lesson is being communicated in any of the exhibits or other programs of the current Presidential Libraries.

Many of the directors and staff of these libraries have articulated these other purposes, especially as they watch the number of researchers decline after a period of the opening of the papers or after the libraries and their exhibit halls have been open for a substantial period of time. So, these institutions have searched for special conferences, revolving and more entertaining exhibitions, and other means by which to be part of the tourist and educational industries. The Director of the Hoover and popular historian, Richard Norton Smith, wrote this eloquent description of the libraries: "Like the office they commemorate, presidential libraries are living institutions. Beyond their glass cases and document boxes, one can breathe the air of history made and history in the making. They are not monuments to one person alone. Rather, they are storehouses of information and classrooms for democratic instruction. In recent years especially, they have become popular places for Americans of every age to examine their past and explore a history not always learned in school. ${ }^{-61}$ While it is hard to argue with the possibilities for these libraries to meet such a broader purpose, one wonders whether these kinds of statements are simply part of a desperate effort to reinvent these institutions in the face of mounting problems about their relevance. The larger, and more important, question is whether these purposes could not be met through other means other than the building, staffing, and maintaining of these elaborate facilities?

In fact, some current leaders of these institutions wish for more power to be given to the former Presidents to control their own records. Don Wilson, Director of the Bush Presidential Library Center, believes that the recent efforts to legislate the control of these records have had a negative impact on the records themselves: "What, one might consider, is the impact 
on the historical record of the Presidency over the past 25 years of litigation and debate?" This is certainly a legitimate question. "Research," Wilson continues, "has shown that prior to Watergate when a President controlled the papers of his administration and then left office retaining that legal control, a different kind of historical documentation existed. The preWatergate Presidential documentation was more personal in nature-diaries, personal memos from advisors to the President, records of phone conversations, and lengthy memoranda and extensive notes of personal views and thoughts. On the other hand, the postWatergate Presidential documentation is formal, carefully worded and structured, option memoranda and formal minutes of meetings, all bureaucratic in nature." Might not this be the result of the changing technologies being used to create records or the way in which the National Archives has tried to define records? Certainly, electronic mail enables all kinds of informal and personal records generation, but the National Archives itself had to be litigated against in order to encompass e-mail into the parameters of a record or recordkeeping system? "This is not to say that there is less documentation or that the record is less complete," Wilson goes on. "But the post-Watergate Presidential record has certainly changed its nature and form. Those changes continue to occur as the courts take more and more control over Presidential records and the access thereto .... If the trend toward limiting a President's control over White House records continues, it is likely that certain kinds of White House records will never be created.i ${ }^{62}$ Or, perhaps, that certain kinds of illegitimate activities would be engaged in? Some prominent historians have expressed similar sentiments. ${ }^{63}$ How one reconciles the educational and tourist functions with such a view is a bit difficult to figure out. Perhaps, the imperial tendencies of some of these libraries' leaders are the educational message. At the least, it would be interesting to see more explicit proof that the quality of such records diminishes as the government takes firmer control over them.

There is something of the authorized version of history at work in these libraries. As the above commentary suggests, the combination of both a long-standing tradition of personal ownership of these records by their creators and a very cozy relationship between the former Presidents and the custodians of their records in their libraries has created an unhealthy situation. Richard Nixon's dogged defense that he had been unfairly singled out for special treatment by Congress, this body objecting to the agreement Nixon had signed with the General Services Administrator to control and even destroy portions of his records, is evidence of a continuing attitude by Presidents towards their papers even thirty years into the Presidential Library system. The Supreme Court's decision that Nixon's actions unduly threatened important records, requiring unique action, points up an extremely important issue-who or what is responsible for protecting these records?

Much of this stumbles from the fact that the National Archives, which needs to be a watchdog of Presidential recordkeeping and not merely the custodian of the records, has long seen itself in a weak, subservient, or other flimsy role. The weakness of this federal agency, both from legislative authority and internal problems, was dramatically revealed to the public by journalist Seymour Hersh's description of the difficulties concerning the release of the Nixon tape recordings. ${ }^{65}$ One commentator, Brian Chandler Thompson, on this relationship notes that the White House deals with "urgent matters of the moment" and the National Archives with the "long-term view of history," providing both "irony and symmetry in this relationship." But there is deeper crack underlying this relationship, when this commentator 
notes that "There is a self-effacing pride in the modest boast made by an archivist in the Office of Presidential Libraries when he tells White House officials that 'our job is to help make you look good.' ,66 No, the role of the Office and the individual Presidential Libraries ought to be to help ensure accountability at least in the management of these records.

The small, limited nature of the National Archives and the powerful giant of the White House, alluded to by many working in the National Archives, is no excuse given the overriding sentiment of the various legislative acts citing government ownership and public responsibility of the Presidential records. Believing also that any effort to establish controls over Presidential records while they are in current use is doomed to failure, as some in the National Archives seem prone to believe, is an abdication of responsibilities or, perhaps, the result of wrong perspectives regarding the archival mission.67

There is no doubt that individual Presidential libraries proceed through various cycles of development as they become older, their records are opened and mined by researchers, and the time between a particular President's administration grows longer. The question, however, is what these institutions evolve into, modern pyramids holding the remains in an iconic fashion or important educational and government organizations trying to make Americans aware of how accountable these Presidents ought to be to American ideals, law, and the people.68 And to answer such a question, we need to go outside the libraries themselves and see how others view and use them and their holdings. Researchers, such as historians, and other societal groups all have a vested interest in the work of Presidential Libraries and we ought to listen to what such individuals and groups have to say.

\subsection{Others' views on presidential libraries}

Academic historians, certainly the most serious users of the archival records held in the Presidential Libraries, are divided about the role and success of these institutions. While this might not be surprising, given the often acrimonious debates occurring among historians about virtually everything, it is important to listen closely to both their criticism and praise in light of the promises made about these institutions. Historian Frank Freidel, for example, counters the complaints about the lack of use of records in these libraries by arguing that the "presidential collections have been the basis of much significant scholarship" and that "one

of the assets of the presidential libraries is that, because of their specialized nature, the archivists and librarians gain a thorough mastery of the collections and are particularly expert in providing guidance."69 This seems somewhat contradictory to the concerns about the power or control of the National Archives and the libraries over the records being administered.

One will, in a similar spirit, find many positive and even glowing acknowledgments in books based on the records located at the Presidential Libraries. "Never in my experience as a writer have I had more painstaking, intelligent, unsparing co-operation than was given by Herman Kahn, director of the Franklin D. Roosevelt Library at Hyde Park. A knowledgeable and dedicated authority, Mr. Kahn has gone far beyond ordinary courtesy in assisting the authors. He has suggested sources of corroborative information, and has been a judicious, scholarly arbiter of many questions concerning F.D.R. Appreciation also is due the Library's capable staff. ,70 "Research is a lonely task, but the loneliness in this case was offset by the 
companionship of Richard Roveres and of the staff of the Roosevelt Library ",,71 "Every writer about FDR and his times is immeasurably indebted, directly or indirectly, to the Franklin D. Roosevelt Library of Hyde Park, New York .... I am continuously acutely conscious of how much I owe to these earlier authors and, through them, to the library's remarkably efficient and helpful staff." ${ }^{72}$ Hundreds of such statements grace the acknowledgments pages of scholarly books about twentieth century politics, Presidential administrations, political biographies, and other sources requiring the use of the Presidential Libraries.

While there can be no doubt that researchers are treated in a courteous and helpful manner, many historians and other scholarly researchers have raised questions about the relevance of the Presidential Libraries. Thirty years ago historian Herbert Feis wrote that the libraries were of little help in making records concerning foreign policy available in a timely fashion. Feis admitted that the "presidential and other memorial libraries will later on be of service and value to those who write of the safely outdistanced past. But unless present and prospective rules and restrictions are relaxed, they will not aid those who want to study and write about the ... recent past." He continued, "The creation of these libraries was bathed in the light of promised revelation. They were not conceived merely as memorials and preservative depositories. They were hailed because of the belief that they would enable the American people to learn more-and more easily and quickly-about their past. But the light of revelation is now so filtered through curtains of reserve that the value of these institutions to the historian of the recent past is still to be proven." Feis believed he detected a kind of imperial guard working in the libraries: "Thus all the papers that may be collected by the magnetism of reputation or association are in the custody of officials who are well stitched into the executive webbing and subject to orders. In decisions about throwing open to general inspection records in the upper realm of historical interest, these archivists neither can nor will exercise independent judgment." Feis speculated that the "officials and trustees who are guardians of these collections may regard themselves also as guardians of the reputation of the memorialized individual. They may be loath to expose that reputation to sting or stain as long as living persons care deeply." 73

Feis's worries are not those of a single, academic curmudgeon or alarmist. Numerous other historians and researchers have expressed similar concerns. While there have been extreme cases of accusations, such as in 1969 when Francis L. Loewenheim and nineteen other historians accused archivists at the FDR Library of deliberately withholding documents, most concerns have focused on the system rather than particular instances ${ }^{74}$ Historians like Joan Hoff have pointed out that the Presidential Libraries exist to memorialize the Presidents and reflect the failed approaches of the National Archives in dealing with public records. "As a rule," Hoff argues, "presidential libraries are a bad idea; they have in the past led to many access and secrecy problems, and will continue to do so in the future. In part, these problems are the result of the National Archives' lack of courage in enforcing pre- and post-Watergate records laws." Hoff also contends that "No director of any of these facilities has ever been appointed without the ex-president's, his family's, or his foundation's explicit approval; these institutions exist to enhance the images of the chief executives whose collections they house." 75 Again, these are not the solitary ravings of one person, but they express the worries of many researchers. 
The source of concern relates to whether these institutions can really be independent from political and other interference. A quarter of a century ago, an economics professor matterof-factly stated that researchers "must keep in mind that the Presidential Libraries as they are operated ... are political institutions. First, in the 'extralegal' sense of the word political, they are the places where the fuzziness of the laws and regulations governing public records are probably going to be most highly dramatized. The researcher will have to recognize that rules cannot cover every case and the gray areas are often going to be exposed at this high level of material. But the archivists are government employees, part of the federal mechanism. They cannot be expected to take too many risks on the researchers' side in the gray areas. The institutions are also 'political' in the sense that the managers of each library must be sensitive to the former President (if alive), his family, his former staff, and the institutions which supported the President while in office. The former staff, for example, may still exercise substantial influence within the political party of the former President .... The libraries do, indirectly, serve the political parties, and do so well." 76 Instance after instance, such as the litigation over the Nixon tape recordings or the problems with the management of White House e-mail systems, seems to suggest that rather than Presidential records being maintained as a source of both historical documentation and accountability of government to the public these records are seen as the treasures of an imperial regime.

Returning to acknowledgments found in volumes written about Presidential administrations, we can find additional evidence of a kind of official or authorized studies reflecting an imperial viewpoint. A biographer of Herbert Hoover noted that the impetus for doing his research was his invitation "by a nonprofit, educational foundation in Iowa to prepare a comprehensive, independent, scholarly biography of America's only Iowa-born president. The name of this foundation is the Herbert Hoover Presidential Library Association. Some years before, it was responsible for construction of the Herbert Hoover Presidential Library, which is now administered by the federal government through the National Archives and Records Service." The biographer noted "Under the terms of my contract with the Association, all decisions concerning the contents of the biography-including fact and interpretation, proportions and emphasis, inclusions and exclusions-are mine alone. No attempt has been made to control, circumscribe, or alter my research or my findings. The biography that I am writing was explicitly intended to be-and is-a work of free and independent scholarship." 17 On the surface, this is a rather noncontroversial statement, reflecting the challenges of getting to some of the remote locations of the various Presidential Libraries (the Hoover is in West Ames, IA), but there are deeper concerns here. First, the dispersal of the Presidential papers through a loosely knit confederation of Presidential Libraries has long been a source of concern by researchers. ${ }^{78}$ Second, there appears to be instances when individual Presidential Libraries have impeded the use of records by a particular researcher because of dissatisfaction about that use by a former President's family. ${ }^{79}$ Third, some observers contend that the relationship between the National Archives, the Presidential Libraries, and the former Presidents and their associates makes for a system not providing sufficient oversight and impartial decisions. ${ }^{80}$

With such inherent weaknesses (and here, I surmise, even the appearance of such weaknesses is a serious matter), one is left with a system that is more useful for tourism, the local economy, and unbridled hero worship than any useful role in keeping Presidents 
accountable to Congress and the American people. It is one thing for a children's book to accentuate the positive, citizen-building characteristics that might be found in a Presidential Library,"' but it is altogether different when others, in important public policy and popular journals, are writing about these institutions as "shrines" and "memorials." Roger Rosenblatt, commenting on the opening of the George Bush Library in College Station, Texas, wondered why the place is called a library, when there are not many books there? "For that matter," Rosenblatt mused, "why should any presidential library be called a library-especially when the buildings are not primarily collections of written works, but shrines to a particular president's alleged greatness?" He believed that very few of these Presidents had distinguished themselves, but noted that there are eleven such libraries. "Statues used to be sufficient for satisfying the self-aggrandizing impulses of world leaders .... But what a statue used to accomplish now takes an entire library. It must be that a library is commonly recognized as an establishment of dignity, and therefore presidents, who always seem to seek a place in history, find that calling their monuments libraries certifies their historical importance." "' 2 And here we have the public debate opening up about Presidential Libraries and their purpose.

Everybody has an opinion about Presidential Libraries. They easily appeal to basic patriotism. Malcolm S. Forbes, Jr., critical of recent discussions in Congress and the National Archives to end the Presidential Library system, writes: "Through imaginative exhibits, they bring the President and his times to life. They provide an absorbing education to hundreds of thousands of Americans each year, a particularly important function in an age when too many of our schools disparage or distort our past." Others simply cite the regular use by scholars and museum visitors. ${ }^{84}$ Not surprisingly, many individuals see the connection of the libraries to the localities as the most crucial aspect of their mission and value, often revealing a deep-seated anti-Washington, D.C. attitude. Travel writer William Zinsser, writing about Abilene and the Eisenhower Library, reflected on some of the previous debates about the scattering of presidential records, but concluded that "Today such disregard for the convenience of scholars and the preservation of public records wouldn't be tolerated; as citizens we expect to find a presidential library open for business in towns that our modem Presidents have called home .... Such feelings go much deeper. Picking up on an internal personnel squabble at the National Archives Office of Presidential Libraries, one local columnist went out on the limb to argue that the then acting Archivist of the United States, Trudy Peterson, wanted to control the Presidential Library system, arguing that Peterson "desperately wants the Washington office to totally control every jot and whit of presidential library activity. If Trudy's plan goes into place there will be no future camaraderie between the mayor of Independence and the director of the Truman Library ... the whole she-bang will be run out of Washington. The easy-going tradition of the Truman Library, exemplified by the pleasure that Mr. Truman got by personally escorting groups of school children around his building, will come to a screeching halt. Absolutely nothing will take place on the grounds that Mayor Bob Weatherford purchased and donated to Mr. Truman ... without the prior written approval of the National Archivist, whoever he or she is at the time." 86

There is a sort of apologetics in place for explaining Presidential Libraries. Bernard Weisberger, in a popular article, suggests a kind of trying the best to work within an imperfect situation: "If the President exerts his right to put his papers in a marble monument 
built by hometown friends in a location far from traditional seats of learning, the conscientious archivist has no choice but to follow them there, care for them, display them under whatever conditions are allowed. If he is a truly hard-working archivist-as all the Presidential library directors are-he will urge the President's co-workers also to deposit their papers there. He is not likely to get such deposits without being able to give assurances that the public will not soon be let into the donor's inner life; as the mediator between the future historian and the gun-shy subjects of history, his first rule of operation is to get the material preserved. The Presidential libraries have actually hastened a policy of accumulation that would ordinarily have taken generations. ${ }^{~} 87$ For most people, this kind of commentary seems to portray these libraries as archival beggars looking for whatever scraps they can find. Weisberger is, of course, following the line that this kind of institution is the best solution in an imperfect world, such as when he wonders about their ability to deal with modern technologies. He thinks that the "collecting energies of the directors raise some disturbing reflections. The information explosion threatens to bury them in documentation. Clicking Xerox machines, microfilm cameras, and whirling tape reels all proliferate information. In point of fact, even if all future Presidents were compelled to leave their official records in Washington, it would be necessary to build completely new repositories to hold them, simply because of the multiplying size of the Executive Department and because its officials, like those of all Washington, are pouring out a rising flood of paper." 88 This is truly a problem since Wesiberger's article is thirty years old, written at a point when such technologies were much simpler.

Many of the popular sentiments about Presidential Libraries focus on the museum or educational roles of the institutions, instead of the matter of the records. There may be some very specific and understandable reasons for this. Geoffrey Ward argued that FDR was determined to secure his place in history, but that "His fierce drive to insure his place in history kept him from discarding anything. But that impulse was nearly matched by his lifelong love of secrecy. He could never be persuaded to sign a formal deed of gift for his papers. Instead, he dictated a memorandum in 1943 setting up a 'Committee of Three' of his most trusted aides to winnow through them should he not live to do so, deciding which should be released, which sealed for a time and which withheld forever." ${ }^{89}$ It is far easier for these institutions to focus on commemorating the former Presidents rather than bringing up the more difficult matters of ownership, access, and revelations in their papers. Again, will we learn about the failures of Presidents? Will we learn about misguided decisions made by a particular administration? Will the voice of the people be heard through all the celebratory texts found in the museums of these libraries?

The question about the museum or educational functions is just what these libraries will educate the public about. A museum educator, Victor J. Danilov, examining the controversy over the Nixon library, speculates that this controversy has "focused attention on a dilemma facing all museum professionals at presidential libraries: how to deal with sensitive topics in telling the story of a president and his times." Danilov also recognized the problem in the exhibitions "because the museum typically is a tribute to a person who is involved in the planning and he or his family normally continue to watch over its operations." 90 Twenty years ago, Louis Leonard Tucker, an historian and director of a historical society, noted, "While the early libraries contained museum exhibits, they were principally conceived as 
research centers. In the recent structures, the museum components have become the dominant element." But Tucker worried that "As a historian, I have another and more vexing worry: the effect these recent huge structures have on the historical perception of a president by the general American public. These massive structures, with their elaborate, dramatic, and sophisticated museum programs, make a profound symbolic statement about the individuals they memorialize. Their size and pretentiousness connote the view that these were 'Great Men' who were involved in 'Great Deeds.' They magnify not only the importance of the presidents but also the events in which they were involved. Every administration assumes the dimensions of a 'Heroic Age.' "91 In other words, these are not easy institutions to figure out how to develop educational programs for, unless we glibly accept the fact that they are intended to commemorate the Presidents and the American Republic. Can we really expect that they can develop exhibitions that will portray a particular administration in an honest manner, warts and all? This seems to be a naive hope.

\subsection{Is there a future for presidential libraries?}

Where do we go with resolving what to do with Presidential papers and the growing library system supporting them, assuming that one agrees that there are some fundamental flaws with such a system? What kinds of proposals have been made? John Berry, an outspoken critic of federal information policies, laments the "inability of the private founders and funders of the presidential libraries ... to separate their obvious pride in 'their' president from the nation's need for a fully accessible repository containing the entire record of an administration, good news and bad." Berry sets forth a very straightforward recommendation for change: "Clearly the responsibility for insuring access to these invaluable records is far too important to be left in the hands of presidential aides, partisans, or supporters. That job must be completely given over to the neutral hands of the professionals in the National Archives." ${ }^{92}$ However, the National Archives seems not to have taken leadership in this or many other federal records matters, sometimes a matter of resources or authority and other times a matter of poor leadership or confused views about mission and responsibilities.

Others have lamented the problems with the libraries, but simply throw up their hands and conclude that they nevertheless remain the best solution. Donald McCoy, a historian who wrote the best history of the National Archives, terms the library system a "mixed legacy. It has been a boon for researchers interested in aspects of only one presidency as well as for tourists and the economies and even educational facilities of the towns in which such depositories are found. Researchers interested in more than just one administration, as most are, have found it a burden on their time and financial resources. There are those who also find repellent the aspect of a shrine that the presidential libraries and similar institutions assume. There is no fair way to satisfy all the people involved, for wherever the research materials would be located someone would be at a disadvantage. One can, however, suggest that without the presidential libraries far less historical documentation would have been deposited and made available to the public." 93 McCoy aptly summarizes the difficulty of this . complex problem, especially the problem about trying to satisfy everyone. The one aspect he neglects, however, is that of maintaining Presidential records as a form of accountability by a democratic government to the citizens it serves. 
Others contend that whatever their limitations, the Presidential Libraries bring a rich variety of historical resources together, papers and artifacts, in a manner enabling us to see things in a different light. One commentator noted three decades ago, "to evaluate the libraries solely as manuscript depositories slights other aspects of their operation and does not show what distinguishes presidential libraries from other archival institutions. The presidential papers and other such documents cannot by themselves show the many sides of a President's era. Making the papers available to the researcher remains the libraries' primary job, but it is bringing them together in 'creative juxtaposition' with the museum objects and physical settings associated with the Presidents that makes the libraries unique. ${ }^{94}$ This is an excellent point, but it is only a point worth making if such juxtaposition is used to educate the public about the nature of Presidential powers, failures, and prospects-not merely praising the deeds of great men.

The main difficulty in trying to resolve the dilemma posed by Presidential Libraries is the right that each President believes he has to inherit a library at the end of his administration and the expectations by that President's hometown or alma mater that they will gain the prestige or economically friendly tourist attraction of such a library. The problem with the current system is that it bypasses the importance of records for providing a level of accountability of a particular Presidential administration to the people in favor of simple commemoration and scholarly research interests (such interests will never be fully served unless there is a full documentation to begin with). A closely related problem is the apparent weakness of the National Archives to adopt either a fuller view of the value of records for accountability and evidence or to promote such a perspective. This minimizes the value of the National Archives assuming a watchdog role and certainly weakens the argument that all Presidential records should be centralized in Washington, D.C. under the National Archives. This is what leaves us with an "oh, well, I guess the current system is the best solution we can come up" resignation. Now we have ample tradition of this library system, even though it appears confusing with its mix of public ownership of records and private maintenance of their facilities.

Do we really need a library for each President, each armed with its own archivists and museum curators and scattered about the country? Why not a single institution dedicated to the study of the Presidency, staffed by experts in these records and featuring exhibitions, public conferences, and other events intended to help us understand this office and upping the responsibility for greater accountability by our top officials to the people they serve? Surely the fact that an increasing portion of future documentation of our Presidents will be electronic, resolves the arguments about storage space-unless these institutions are more interested in the museums (the monumental functions)? Why not create an institution allowing greater independence from the interference by the former Presidents, their heirs, or their proteges? The kind of public policy centers affiliated with some of these libraries, such as at the Carter library, ${ }^{95}$ can also be affiliated with a major Presidential research facility or the various former Presidents can feel free to establish these on their own. Whether this Presidential center is under the authority of the National Archives depends on whether the National Archives is given or assumes the authority to deal effectively with the Presidency.

The only effective way for this to happen is for a far-sighted incumbent President to declare that he or she will not establish a separate library, choosing instead to work with 
Congress in a bi-partisan manner to establish a Presidential research center. The origins of the system stem from the actions of another farsighted President, Franklin Delano Roosevelt, but it is not necessarily the case that his vision of more than sixty years ago is still relevant for our modern society. FDR's library was established before Watergate, Filegate, electronic mail and other electronic records, and a host of other transformative events and technologies. A modern solution to Presidential records seems worthy of consideration, one that makes the American public not just gaze with curiosity at the doodles of JFK in an exhibition chronicling the loss of Camelot but in which they can see the records being used to keep our highest officials accountable to the public these officials supposedly serve.

\subsection{Summing up: a policy recommendation}

We need a single Presidential Archives, housed in a facility run by the National Archives (although an empowered archival agency) in or nearby Washington, D.C. where the records of all subsequent Presidential administrations will be stored conveniently for researchers and the public. This facility should focus on records, with some space for small revolving exhibitions about the history and nature of the Presidency, but its primary purpose will be archival. Public exhibition space should be modest (especially since other D. C.-based institutions, such as the Smithsonian's Museum of American History, can be more than adequate in educating the public about the Presidency), but there ought to be more space allocated for conferences and meetings about the Presidency, the American political system, and national and international affairs.

As is the usual way of doing business in the federal government, a study commission of nonpartisan politicians, scholars, archivists, and prominent citizens probably will need to be established to sketch out new arrangements for Presidential records. Regardless of how it may be done, there are some obvious issues that will need to be considered and resolved in light of a new environment in which Presidential administrations operate. The quantity of records will increase, but the physical space necessary to house them will decrease as many of the new records systems will be digital. The consolidation of the records into a single facility will bring economies of scale enabling a trimming back of costs in preserving and making available the records while also concentrating professional staff who can deal with the increasingly complex technologies supporting Presidential records systems. With this more focused mission on the Presidential records, the archives staff can work to use the best available technologies for disseminating information about the records and expediting access remotely when possible.

The most important benefits of a dedicated Presidential archives would be enhancing the possibilities that access to these records will be improved along with the value of these records for the nation's memory, scholarly investigations, and ensuring the accountability of our highest elected and appointed officials. As I have tried to show in this essay, the Presidential Library system has grown but it has not been an effective advocate (in outcome at least) for the openness of government records. Establishing a dedicated facility will require stronger legislation governing Presidential records, perhaps with a strong (high profile) advisory group, and this legislation must also strengthen the National Archives in much the same way as Inspector Generals work within agencies as independent watchdogs to protect 
the interests of the government, government workers, and its citizens (whose interests ought to be one and the same). At this time, the work of the National Security Archive, a "non governmental, nonprofit institution," provides the kind of aggressive monitoring about federal records and access to them that ought to be emulated by the National Archives and a new Presidential Archives (unless we hold to the idea that Presidential records are mostly for Presidents and their advisors). ${ }^{96}$

No one in Congress or any Presidential administration a half-century ago had any expectations that Presidential Libraries would be touted as tourist attractions or be seen mostly as educational programs. While it would be ludicrous to argue against educating any American student or citizen about the Presidency, there is no reason to think that such education must come via the Presidential Library system or that it is more important than the archival function which is at the base of an accountable government and any reasonable prospects for understanding Presidents and their administrations. A single Presidential Archives can achieve this, and, more importantly, it can switch the focus from a memorializing of Presidents as heroes and leaders to educating citizens about the importance of accountability in a democratic government and the fact that records (as evidence and information) are the foundation for this. Besides, Presidential records are not local community assets, they are national assets deserving their treatment in a way appropriate to such status. And, Presidential records are not devices for creating a uniquely American mythology, but they are windows into how our government and its leaders work, lead, negotiate, make mistakes, and rectify their errors.

Of all the claims made in behalf of Presidential Libraries-that they aid in attracting more records, expedite their opening, encourage model public-private partnerships, and bring people closer to their government-there is no reason to believe that a dedicated Presidential Archives would undermine any such benefits. Indeed, there is reason to think that a dedicated program and facility might improve these and other functions by refocusing on the records and their value, lessening the interference of family members, and consolidating records expertise near the nation's capital under the closer scrutiny of government, citizens, and the media.

As to the fears that any other arrangement than the present Presidential Library system would lead to the destruction or lack of creation of records because of records compromising or misinterpreting Presidential actions, decisions, and initiatives, this seems, at best, a deal with the Devil. If the only means by which to ensure that records are created in the first place is to develop a system where there is loose control and minimal safeguards in enabling access, there is little point in such a system anyway. A strong Presidential Archives, and a strong National Archives, should be able to ensure that Presidential records are safe and accessible. To think otherwise, however pragmatic it might appear to be, is to work in risk of the failure of a democratic system. We have long since resolved the question of who or what Presidential records belong to-they belong to us. Now it is time to end the current system (at least end the addition of any new Presidential Library) and emphasize a process protecting us and Presidential records.

Establishing a different kind of Presidential Archives will end the cult of personality' that seems to be in place with the current Presidential Library system. So many commentaries describing how the former President or his family must be carefully handled in order to 
secure full cooperation seems hardly fitting in a democratic society. A separate Presidential Archives could focus more on the office, the democratic process, all while not ignoring the character of the individuals who have held the office. As it is, we gain a more intimate portrait of the President in watching West Wing on television, however skewed that portrayal might be, than we do in recreations of Oval Offices around the nation with noncritical exhibitions and accompanying gift shops. A single Presidential Archives would substantially improve our ability to learn about the Presidency in a more realistic fashion, no matter how imperfect or what challenges we might face in doing this.

The real hero is not Franklin Roosevelt for his leadership in creating this present system, but the many archivists who have worked under difficult circumstances to preserve and make the records available to the public and scholars. Now we need another heroic advocate to create a different kind of Presidential Archives.

\section{Notes and references}

1. Christopher Marquis, "Government Is to Pay $\$ 18$ Million for Nixon Material It Confiscated," New York Times, 13 June 2000, p. Al, 21.

2. William Zinsser, American Places: A Writer's Pilgrimage to 15 of This Country's Most Visited and Cherished Sites (New York: HarperCollins, 1992), p. 6.

3. Pat Hyland, "The Presidential Libraries: A Growing Resource," Public Libraries 36 (March/April 1997): 94.

4. This information is available at "Presidential Libraries of the National Archives and Records Administration," at http://www.nara.gov/nara/president/overview.html. accessed 12 September 2000.

5. Philip C. Brooks, "A Special Library for the Presidency," Missouri Library A ssociation Quarterly 23 (June 1962): 42.

6. Hyland, "The Presidential Libraries," pp. 95, 99.

7. Don W. Wilson, "Presidential Libraries," Prologue 21 (Summer 1989): 100. Wilson also contends that the records are more accessible: "On average, however, most of the papers of presidents in the presidential library system become available for research on an equal basis some six to seven years after the president's term of office ends. Compare this with the fact that the papers of Abraham Lincoln were not available for public use until 1948, or the distressing fact the papers of John and John Quincy Adams remained locked up tight in the Massachusetts Historical Society until the 1950." Wilson also thinks that the libraries are "less monuments to great men than classrooms of democracy" (p. 773). Don W. Wilson, "Presidential Libraries: Developing to Maturity," Presidential Studies Quarterly 21 (Fall 1991): 771-779.

8. Lester J. Cappon, "Why Presidential Libraries?" Y ale Review 68 (Autumn 1978): 16.

9. Francis Russell, "The Shadow of Warren Harding," Antioch Review 36 (Winter 1978): 57-76.

10. Quoted in "Who Owns Presidential Papers?" Manuscripts 27 (Winter 1975): 8.

11. Cynthia J. Wolff, "Necessary Monuments: The Making of the Presidential Library System," Government Publications Review 16 (1989): 48-49. 
12. Raymond Geselbracht, "The Four Eras in the History of Presidential Papers," Prologue 15 (Spring 1983): 38.

13. Such as "For whatever faults and problems are involved, Presidential Libraries have been immensely important because they provided for a uniform system of control and access to presidential papers. There could be no greater mistake than to return to the nineteenth century presidential practices of laissez-faire." Arnold Hirshon, "The Scope, Accessability and History of Presidential Papers," Government Publications Review 1 (Fall 1974): 374.

14. Geselbracht, "The Four Eras," 37.

15. James B. Rhoads, "The Papers of the Presidents," Proceedings of the Massacushestts Historical Society 88 (1976): 96.

16. R. D. W. Connor, "The Franklin D. Roosevelt Library," American A rchivist 3 (April 1940): 83-84.

17. Quoted on p. 83 in R. D. W. Connor, "The Franklin D. Roosevelt Library."

18. Samuel B. Hand, "Rosenman, Thucydides, and the New Deal," Journal of A merican History 55 (September 1968): 334-348.

19. R. D. W. Connor, "The Franklin D. Roosevelt Library," 89-90.

20. Geselbracht, "The Four Eras," 38; R. D. W. Connor, "The Franklin D. Roosevelt Library," 85-86. Don Wilson contends that FDR was impressed with the Rutherford B. Hayes Presidential Center established in 1916. Don W. Wilson, "Presidential Libraries: Developing to Maturity," p. 771.

21. Waldo Gifford Leland, "The Creation of the Franklin D. Roosevelt Library: A Personal Narrative," American A rchivist $\mid 8$ (January 1955): 13.

22. R. D. W. Connor, "The Franklin D. Roosevelt Library," 81.

23. William J. Stewart and Charyl C. Pollard, "Franklin D. Roosevelt, Collector," Prologue I (Winter 1969): 27. For a similar article, see Leonard DeGraaf, "FDR as a Collector of Books and Manuscripts," AB Bookman's Weekly 84 (November 6, 1989): 1773-1777.

24. Fred W. Shipman, "Franklin Delano Roosevelt, 1882-1945," American A rchivist 8 (October 1945): 229.

25. Elizabeth B. Drewry, "The Role of Presidential Libraries," The Midwest Quarterly 7 (October 1965): 56-57.

26. George Lardner, Jr., "Release of Reagan Documents Put on Hold: White House Reviewing Secret Papers, Some Dealing with Current Bush Officials," Washington Post June 10, 2001, p. A05, available at http://www.washingtonpost.comlwp-dvn/ articles/A 45939-200lJun9.html, accessed June 11, 2001.

27. Quoted in Geselbracht, "The Four Eras," p. 39.

28. Quoted in Wolff, "Necessary Monuments," p. 51.

29. R. D. W. Connor, "The Franklin D. Roosevelt Library," p. 88.

30. Donald R. McCoy, "The Beginnings of the Franklin D. Roosevelt Library," Prologue 7 (Fall 1975): 147.

31. Philip C. Brooks (director of Truman), "The Harry S. Truman Library: Plans and Reality," American A rchivist 25 (January 1962): 25-37. 
32. Dan H. Fenn. Jr., "Launching the John F. Kennedy Library," A merican A rchivist 42 (October 1979): 429-442.

33. Raymond H. Geselbracht and Daniel J. Reed, "The Presidential Library and the White House Liaison Office," American A rchivist 46 (Winter 1983): 71.

34. Geselbracht, "The Four Eras," p. 42.

35. James B. Rhoads, "The Papers of the Presidents," Proceedings of the Massacushestts Historical Society 88 (1976): 94.

36. Pamela R. McKay, "Presidential Papers: A Property Issue," Library Quarterly 52, no. 1 (1982): 21-40.

37. Susan Naulty, "Creating an Archives at the Richard Nixon Library and Birthplace," Government Information Quarterly 11, no 1 (1994): 37-45.

38. Lester J. Cappon, "Why Presidential Libraries?" Y ale Review 68 (Autumn 1978): 28, 33.

39. Anna Kasten Nelson, "The Public Documents Commission: Politics and Presidential Records," Government Publications Review 9 (September-October 1982): 450.

40. Nelson, "Public Documents Commission," 448.

41. Nelson, "Public Documents Commission," 447, 450.

42. Stephen Burd, "Gingrich Would Cut Aid to Presidential Libraries," Chronicle of Higher Education, 41 (13 January 1995), p. A27.

43. Dennis A. Daellenbach, "The Ronald Reagan Presidential Library," Government Information Quarterly 11, no. 1 (1994): 23-35.

44. See the NCC Washington Update, Vol 6, no. 30, September 8, 2000, available at http: //www. h-net. msu. edu/-ncc.

45. William Matthews, "You've got mail," Federal Computer Week, 6 March 2000, at http://www.fcw.cona/fcw/articles/2000/0306/web-email-03-06-00.asp

46. Francis X. Blouin, Jr., "Presidential Libraries in the United States," Janus no. 2 (1992): 11, 146.

47. Herman Kahn, "World War II and Its Background: Research Materials at the Franklin D. Roosevelt Library and Policies Concerning Their Use," American A rchivist 17 (April 1954): 151.

48. Philip S. Brooks, "Understanding the Presidency: The Harry S. Truman Library," Prologue 1 (Winter 1969): 8. Elsewhere, Brooks argued about the challenges posed by collecting the personal papers of Presidential advisors. "Acquiring personal papers has involved a series of adventures. We have communicated with more than 400 people and have met many different sets of circumstances. We meet some people who are vain and think their papers are going to tell the whole story, while others who are very modest say that there wouldn't be anything important in their files, whereas actually they may be among the most important papers available. People have various motives in depositing papers in Presidential Libraries. We try to convince them that their papers are important and that while they may be shy about letting people look into their files in the long run they will be performing a public service by making their papers available." Philip C. Brooks, "Missouri's Own Presidential Library," Missouri Library A ssociation Quarterly 30 (June 1969): 154.

49. Geselbracht, "The Four Eras," p. 39. 
50. William D. Aeschbacher, "Presidential Libraries: New Dimensions in Research Facilities," Midwest Quarterly 6 (January 1965): 205-214.

51. Herman Kahn, "The Presidential Library: A New Institution," Special Libraries 50 (March 1959): 110.

52. Elizabeth B. Drewry, "The Role of Presidential Libraries," The Midwest Quarterly 7 (October 1965): 58.

53. Geselbracht, "The Four Eras," p. 40.

54. Philip C. Brooks, "A Special Library for the Presidency," Missouri Library Association Quarterly 23 (June 1962): 51.

55. George Lardner, Jr., "Offer to Back Up Gore Records Was Rebuffed, Aide Says," Washington Post, Wednesday, June 21, 2000; Page A12.

56. For information about Filegate see the site maintained by the Electronic Privacy Information Center at http://www.epic.org/privacy/filegatel Filegate is described as "In June 1996, it was revealed that the White House had requested and obtained the

FBI records on over 400 individuals without their permission. Other unconfirmed news reports now say that as many as 900 files might have been pulled. Many of those individuals were former employees during the previous Republican Administrations. Congress is now investigating the affair and had held several hearings. In addition, many of the individuals are considering filing actions against the FBI for violation of the 1974 Privacy Act." This Center describes itself as "EPIC is a public interest research center in Washington, D.C. It was established in 1994 to focus public attention on emerging civil liberties issues and to protect privacy, the First Amendment, and constitutional values."

57. Philip C. Brooks, "The Harry S. Truman Library: Plans and Reality," American Archivist 25 (January 1962): 27-28.

58. Brooks, "The Harry S. Truman Library: Plans and Reality," 36.

59. Dan H. Fenn. Jr., "Launching the John F. Kennedy Library," American Archivist 42 (October 1979): 442.

60. Frank H. Mackaman, "Human Drama: Presidential Museums Tell the Story," Prologue 21 (Summer 1989): 135, 138.

61. Richard Norton Smith, "A Presidential Revival: How the Hoover Library Overcame a Mid-Life Crisis," Prologue 21 (Summer 1989): 115-116.

62. Don W. Wilson, "Presidential Records: Evidence for Historians or Ammunition for Prosecutors," Government Information Quarterly 14, no. 4 (1997): 346. See, also, Don W. Wilson, "Culture and Conflict: Defining the National Archives," Government Information Quarterly 13 no. 2 (1996): 187-194. In fairness to Wilson, this is not a new view. In the description of a panel presentation by Richard Jacobs on the possibility government may declare Presidential records to be public, Jacobs "observed that should Congress make such papers public property, there is a danger that officials will stop putting thoughts in writing, and such a law would also diminish the political liberty of elected officials. While he would like to see all the papers of a president kept together, he suggested the possibility of differentiating between political and administrative files." "Who Owns Presidential Papers?" Manuscripts 27 (Winter 1975): 11. 
63. A quarter of a century ago Arthur Schlesinger, Jr. worried about legal rulings that all presidential materials are government property, partly because this could have an "appalling effect on presidential documentation .... The real interest of the historian is in a rich, honest and revealing record rather than in instant access; and the more he pushes for instant access, the more he will impoverish the record." Arthur Schlesinger, Jr., "Who Owns a President's Papers?" Manuscripts 27 (Summer 1975): 181.

64. See Arnold Hirshon, "Recent Developments in the Accessibility of Presidential Papers and Other Presidential Historical Materials," Government Publications Review 6, no. 4 (1979): 343-357.

65. Seymour M. Hersh, "Nixon's Last Cover-Up: The Tapes He Wants the Archives to Suppress," New Yorker (December 14, 1992): 76-82, 84-88, 90-95.

66. Brian Chandler Thompson, "Making History: The Sitting Modern President and the National Archives," Government Information Quarterly 12, no. 1 (1995): 19.

67. President Ford developed a White House Office Manual that required none of his staff to remove their papers when they left; however as Horrocks, supervisory archivist at the Ford suggested, the lack of compilance with the manual "is also a warning on the folly of expecting too much from the attempted enforcement of unpopular or inconvenient recordkeeping rules." David A. Horrocks, "Access and Accessibility at the

“ Gerald R. Ford Library," Government Information Quarterly 11, no. 1 (1994): 50-51.

68. That this is problematic can be seen from within the Presidential Library system. Former Archivist of the United States, Don W. Wilson, believed these libraries tend to have three stages: "Stage one is the museum development and archival processing period; stage two is the professional use or research period; stage three is the nostalgia period, which heralds a reexamination and recollection of the man and his times"; Wilson, "Presidential Libraries," p. 101. Larry J. Hackman, Director of the Truman Library, looked to a future in which these libraries make research collections available online, enhance preservation, offer new exhibits, develop new educational programs allowing schools to use primary sources, and find ways of generating new financial resources to meet these objectives; Hackman, "The Truman Library: A Resource for Missouri, the Nation, and the World," Missouri Library World 2 (Spring 1997): 2-7.

69. Frank Freidel, "Roosevelt to Reagan: The Birth and Growth of Presidential Libraries," Prologue 21 (Summer 1989): 111.

70. James Roosevelt and Sidney Shalett, Affectionately, F.D.R.: A Son's Story of a Lonely Man (New York: Harcourt, Brace \& Co., 1959), p. 374.

71. Joseph P. Lash, Eleanor and Franklin: The Story of Their Relationship, Based on Eleanor Roosevelt's Private Papers (New York: W.W. Norton and Co., Inc., 1971), p. $x v$.

72. Kenneth S. Davis, FDR: Into the Storm 1937-1940: A History (New York: Random House, 1993).

73. Herbert Feis, "The Shackled Historian," Foreign Affairs 45 (January 1967): 339, 340. Herbert Feis, "Unpublic Public Papers," Journal of Historical Studies 2, no. 4 (1969):

, 266-271 (orginally published in the April 21, 1968 New York Times).

74. For information about the case from different sides, see Herman Kahn, "The Long- 
Range Implications for Historians and Archivists of the Charges Against the Franklin D. Roosevelt Library," American A rchivist 34 (July 1971): 277-284; Richard Polenberg, "The Roosevelt Library Case: A Review Article," American A rchivist 34 (July 1971): 277-284; and Francis L. Loewenheim, "A Statement in Rebuttal," December 12,1970, a mimeographed report personally prepared by Loewenheim.

75. Joan Hoff, "The Endless Saga of the Nixon Tapes," in Athan G. Theoharis, ed., A Culture of Secrecy: The Government Versus the People's Right to Know (Lawrence: University Press of Kansas, 1998), pp. 115, 133.

76. James L. Cochrane, "The U.S. Presidential Libraries and the History of Political Economy," History of Political Economy 8 (Fall 1976): 425-426.

77. George H. Nash, The Life of Herbert Hoover: The Engineer 1874-1914 (New York: W.W. Norton \& Co., 1983), p. x.

78. Differing views are evident. Lester J. Cappon argued, "The complaint concerning decentralization of these libraries throughout the United States and the concomitant inconvenience to researchers may be countered by pointing out that, quite aside from the risk of centralization in an age of nuclear weapons, the researchers themselves are scattered throughout the country, so that a library's location, advantageous to some, is ipso facto disadvantageous to others"; Lester J. Cappon, "Why Presidential Libraries?" Yale Review 68 (Autumn 1978): 26. Arnold Hirshon countered, "The Presidential Records Act and its recognition of public ownership of the papers only highlights the absurdity of continuing the Presidential Libraries Act. These expensive, highly decentralized monuments must be halted. Meaningful research cannot be limited to a president's term of office, and this requires that the researcher seeking primary source material must travel to many remote locations. Archival control in the nation's capital in buildings built and maintained with federal monies is surely the next major step which must be taken by legislators." Arnold Hirshon, "Recent Developments in the Accessibility of Presidential Papers and Other Presidential Historical Materials," Government Publications Review 6, no. 4 (1979): 354.

79. JFK biographer Nigel Hamilton accused the Kennedy family of blocking his access to Kennedy's papers because of this family's dissatisfaction with his emphasis on JFK's sex life and his assessment that Kennedy's father may have sexually abused his retarded daughter Rosemary. "Writer Shelves Volume of JFK Biography, Blames Kennedy Opposition," Chicago Tribune, 9 June 1994. Others have lodged similar complaints. Ronald Kessler describes that Nigel Hamilton, Stephen E. Ambrose, and John H. Davis have all complained that the JFK Library does not allow access, complementing their stories with his own experiences. Kessler had access to the full copy of a typescript oral history of Patrick Munroe, a man who knew JFK on the PT-109. At the Library there is a half page blanked out-reference about going to a party in Las Vegas given by Sinatra and Peter Lawford where Judith Exner was present. The library also blanked out a quarter of a page of an oral history with Laura Bergquist, a journalist. The same text is available without deletion at Boston University Library-the deleted reference relating to Jacqueline Kennedy's problems with the press. The JFK library defends this as protection of people still alive, and Kessler indicates he has heard from others who were not dealt impartially with the 
materials there. Ronald Kessler, "History Deleted," New York Times 30 April 1996, p. All

80. Scott Armstrong, founder of the National Security Archive, describes calling John Fawcett, director of the NARA Office of Presidential Libraries. "I knew that in historical circles Fawcett had become notorious for consistently taking the side of former presidents and the entourages they left in charge of the political management of presidential libraries. Many of his colleagues at the archives were also worried that Fawcett's deference to past presidents might lead him to abandon the archives' obligation to ensure the preservation and accessibility of government records." Scott Armstrong, "The War over Secrecy: Democracy's Most Important Low-Intensity Conflict," in Athan G. Theoharis, ed., A Culture of Secrecy: The Government Versus the People's Right to Know (Lawrence: University Press of Kansas, 1998), p. 146.

81. "National memorial libraries such as this one are of inestimable value to all Americans. In a vast country like ours, all things of a historical and cultural nature should be preserved for future generations. Only in this way can the times in which we live be judged by future generations of Americans." Betty Jean Mueller and Edward Miller, The Franklin Delano Roosevelt Library and Home (New York: Meredith Press, 1966), p. 13.

82. Roger Rosenblatt, "Underbooked," New Republic 217 (December 1, 1997): 16-17.

83. Malcolm S. Forbes, Jr., "Enhancing Our Heritage," Forbes 152 (August 16, 1993): 26.

84. "It would seem to this writer that the concept of presidential libraries is a worthy one, especially when one considers the interest generated by the approximately two million people who visit the six libraries each year. History is also served by those hundreds of scholars who have used the facilities to bring before the public the dissertations, articles, and books that have contributed to a greater understanding, appreciation, and preservation of our national heritage." Robert Hanson, "Hail to the Chiefs: Our Presidential Libraries," Wilson Library Bulletin 55 (April 1981): 583.

85. William Zinsser, American Places, p. 135.

86. Keith Wilson, "National archivist important here," Independence Examiner 31 May 1994.

87. Bernard Weisberger, "The Paper Trust," American Heritage 22 (April 1971): 106.

88. Weisberger, "Paper Trust," p. 107.

89. Geoffrey Ward, "'Future historians will curse as well as praise me,' " Smithsonian 20 (December 1989): 66.

90. Victor J. Danilov, "Proffering Presidents: Curators of Presidential Museums and Libraries Constantly Must Balance the Desires of Ex-Presidents With the History of the Nation," Museum News 70 (January/February 1991): 58.

91. Louis Leonard Tucker, "Presidential Libraries and the Pyramid Race," History News 35 (December 1980): 14-15.

92. John Berry, "Archives or Lightning Rods? Why does controversy hound U.S. presidential libraries?" Library Journal 112 (May 1, 1987): 4.

93. Donald R. McCoy, "The Beginnings of the Franklin D. Roosevelt Library," Prologue 7 (Fall 1975), p. 150. 
94. Garold L. Cole, "Presidential Libraries," Journal of Librarianship 4 (April 1972): 122.

95. The Carter Center, in partnership with Emory University, is "guided by a fundamental commitment to human rights, wages peace by bringing warring parties to the negotiating table, monitoring elections, safeguarding human rights, and building strong democracies through economic development"; see http://www.cartercenter.org/.

96. For information on the National Security Archive visit its Web site at http://www. gwu.edu/-nsarchiv/. 